\title{
Clay mineral association in the salt formation of the Transylvanian basin and its paleoenvironmental significance
}

\author{
Nicoleta BICAN-BRIŞAN ${ }^{*}$ \& Alexandru HOSU² \\ ${ }^{1}$ Department of Life and Earth Sciences, "Babeş-Bolyai" University, 4 Ştefan cel Mare, 400192 Cluj Napoca, Romania \\ ${ }^{2}$ HOLCIM SA, 57 Primăverii, 011973 Bucharest, Romania
}

Received January 2006; accepted July 2006

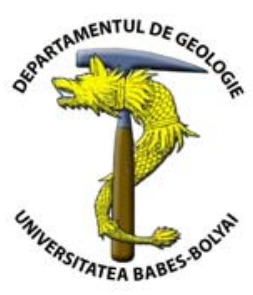

\begin{abstract}
The investigated clay fraction was separated from salt samples recovered from three boreholes located in the Praid salt deposit area. For comparison, samples collected from Turda deposit (Franz Josef adit, the Rudolf and Ghizele chambers) and from the salt massif from Sărățel were also analyzed. The qualitative investigations evidenced a clay minerals association dominated by illite and chlorite accompanied by subordinate amounts of kaolinite, smectite, fibrous clays (sepiolite, palygorskite), and in minor amounts, by 14/14 chlorite/vermiculite and chlorite/smectite interstratifications. A quantitative evaluation (\%) including a standard graphical representation was performed only for the borehole samples (Praid), according to the vertical distribution. The genetical interpretation of the identified clay minerals association took into account the influence of the sedimentation mechanisms and the climate control on the mineral phases. The environment of formation for the salt in the Transylvanian Basin was defined by the presence of specific climatic factors, also suggested by the palynological investigations.
\end{abstract}

Keywords: clay minerals, salt, paleoenvironment, Badenian, Transylvania, Romania

\section{INTRODUCTION}

One of the methods traditionally used for paleoenvironmental interpretations concerning various types of geological formations is based on clay minerals investigation.

This method had to be applied also in the case of the salt formation from the Transylvanian Basin, as an additional genetic study to the recent palynological (Petrescu and Meseşan, 1993; Petrescu and Bican-Brişan, 1997; Petrescu et al., 2000; Petrescu et al., 2001, 2001 a) and tectonic (Balintoni and Petrescu, 2002) investigations. A complex approach is complementary and may lead to similar conclusions, as it was in our case.

The clay fraction separated from salt samples was investigated by using X-ray diffraction (XRD) on oriented samples. The salt samples were collected from the peripheral areas of the Transylvanian Depression, from the Praid, Turda and Sărățel salt massifs (Fig. 1).

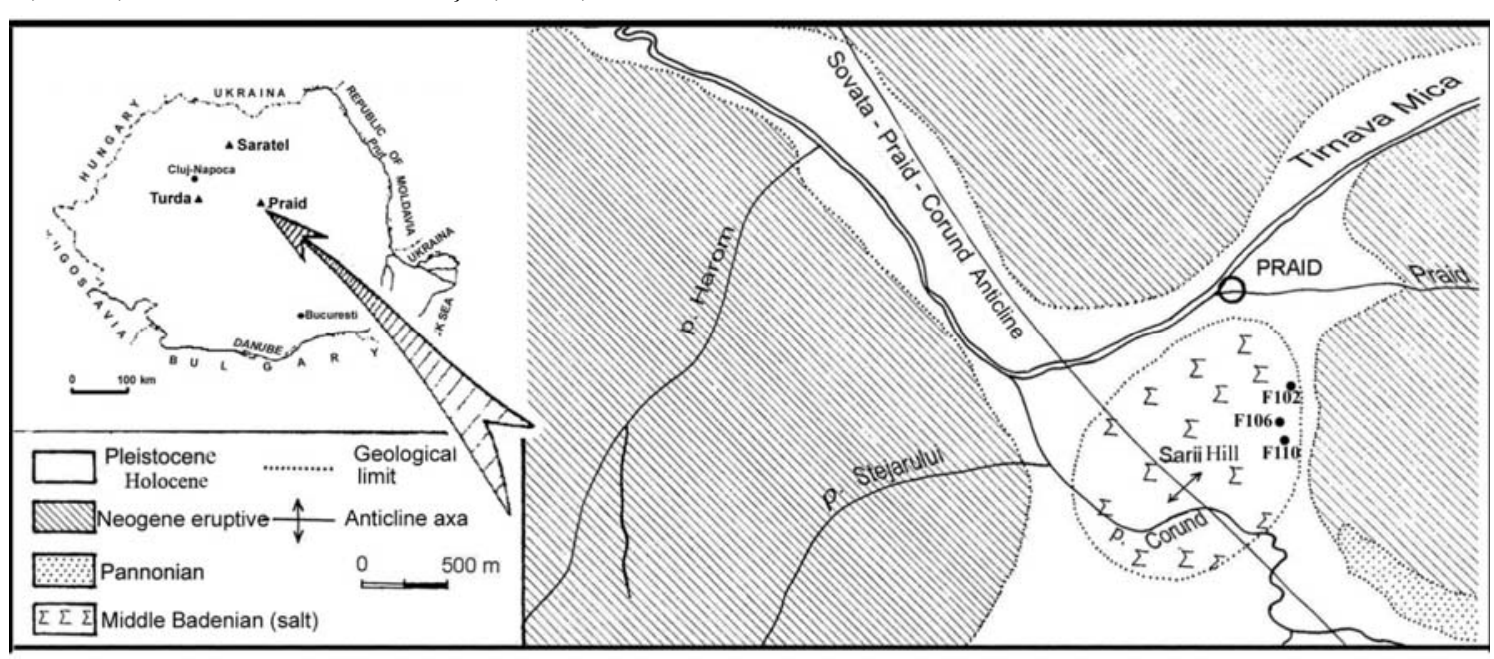

Fig. 1. Location of the studied salt samples. 
The samples from Praid were collected from the three boreholes located in the eastern extremity of the salt deposit (Fig. 1), those from Turda from the Franz Josef adit and the Rudolf and Ghizela chambers, while those from Sărățel originate from the outcrop on the bank of Şieu River, in the north-western extremity of the salt massif.

\section{CLAY MINERALS ANALYSES}

The clay mineral assemblage identified in the salt formation of the Transylvanian Basin consists of dominant illite and chlorite; besides, kaolinite, smectite, and fibrous clay minerals (sepiolite, palygorskite) have been also identified in small amounts, as well as 14/14 interstratifications (mixed-layers) of chlorite/vermiculite, and chlorite/smectite type.

The quantitative composition (\%) (Holtzapffel, 1985) of the clay minerals assemblages is presented in Table 1 .

In the case of the borehole samples from Praid, based on the vertical distribution, the quantitative interpretation followed the standard procedure used for the analysis of clay minerals (Figs. 2, 3, 4).

Table 1. The quantitative composition of the clay mineral assemblage in the studied salt samples.

\begin{tabular}{|c|c|c|c|c|c|c|c|c|c|c|c|c|c|c|c|c|}
\hline \multirow{3}{*}{$\begin{array}{l}\text { Clay } \\
\text { mineral }\end{array}$} & \multicolumn{8}{|c|}{ PRAID } & \multicolumn{4}{|c|}{ TURDA } & \multicolumn{4}{|c|}{ SĂRĂȚEL } \\
\hline & \multicolumn{3}{|c|}{ F102 } & \multicolumn{2}{|c|}{ F106 } & \multicolumn{3}{|c|}{ F110 } & \multirow{2}{*}{ P5 } & \multirow{2}{*}{ P6 } & \multirow{2}{*}{ P7 } & \multirow{2}{*}{ P9 } & \multirow{2}{*}{$3 / 01$} & \multirow{2}{*}{$3 / 02$} & \multirow{2}{*}{$3 / 03$} & \multirow{2}{*}{$3 / 04$} \\
\hline & P1 & P2 & P3 & $\mathrm{P} 4$ & P5 & P6 & P7 & P8 & & & & & & & & \\
\hline Kaolinite & 16 & 13 & 13 & 34 & 33 & 13 & 17 & 13 & 16 & 14 & 15 & 12 & 11 & 17 & 16 & 17 \\
\hline Illite & 32 & 27 & 31 & 42 & 47 & 40 & 34 & 38 & 41 & 39 & 40 & 30 & 35 & 32 & 27 & 30 \\
\hline Chlorite & 34 & 24 & 38 & 23 & 19 & 37 & 30 & 34 & 17 & 30 & 27 & 27 & 30 & 30 & 29 & 29 \\
\hline Smectite & 17 & 20 & 17 & - & - & 9 & 18 & 14 & 20 & 4 & 15 & - & 13 & 8 & 11 & 10 \\
\hline Fibrous clays & - & 13 & - & 0.5 & 0.5 & 0.5 & 0.5 & 0.5 & - & 10 & 1 & 25 & 9 & 10 & 15 & 12 \\
\hline $\begin{array}{c}14 / 14 \\
\text { chlorite/vermiculite } \\
\text { interstratifications }\end{array}$ & - & 2 & - & 0.5 & 0.5 & - & - & - & 1 & - & - & 1 & - & - & - & - \\
\hline $\begin{array}{c}14 / 14 \\
\text { chlorite/smectite } \\
\text { interstratifications }\end{array}$ & 1 & 1 & 1 & - & - & 0.5 & 0.5 & 0.5 & 5 & 3 & 2 & 5 & 2 & 3 & 2 & 2 \\
\hline
\end{tabular}

For the samples from Turda and Sărățel, no quantitative vertical variation of the clay minerals content could be represented in the plot (Fig. 5).

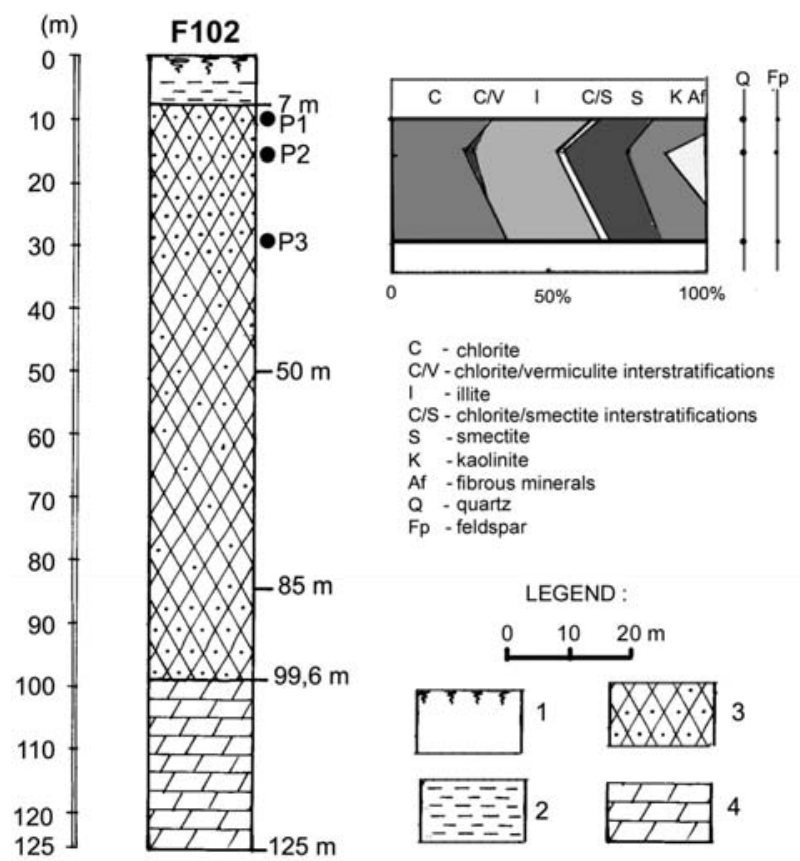

Fig. 2. Borehole F102 - Praid

1. Soil with vegetal rests; 2. Clay; 3. Salt with various amounts of impurities; 4. Marl; P1, P2, P3 - Samples submitted to XRD investigation). Quantitative distribution of the identified clay minerals (upper right).

\section{a. Influence of the sedimentation mechanisms}

The illite/chlorite \pm kaolinite assemblage is typical for clastic sedimentary environments with a medium - to high dynamics (Chamley, 1989).

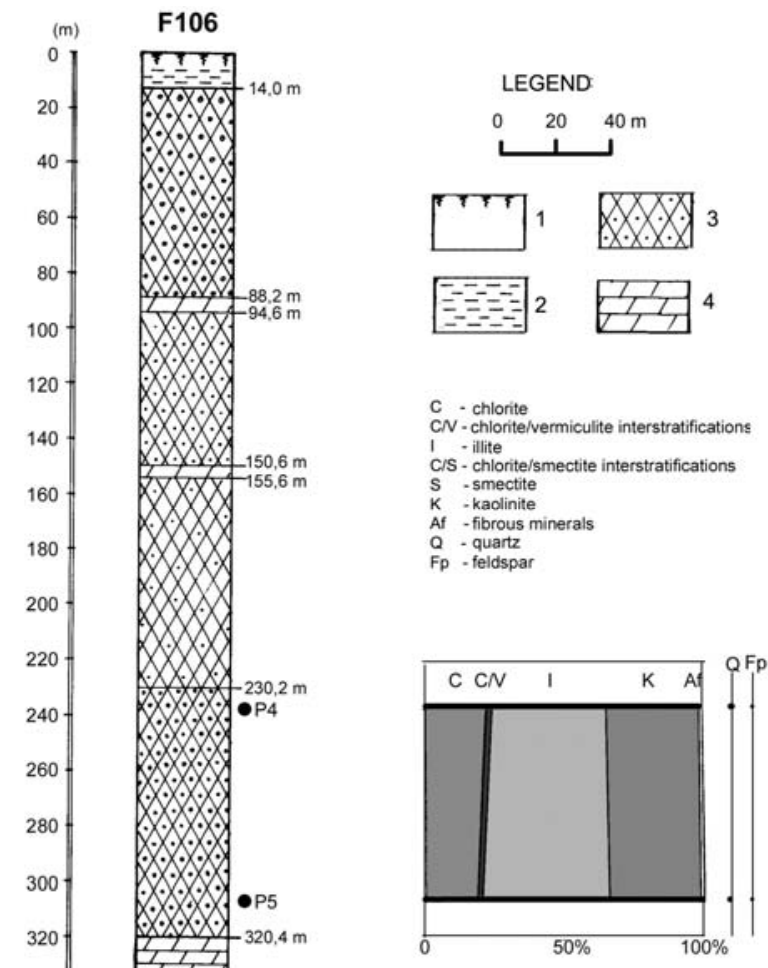

Fig. 3. Borehole F106 - Praid (same legend as for Fig. 2) P4, P5 - Samples submitted to XRD investigation.

The small amounts of smectite in the association may be an additional argument for a high hydrodynamics. It is wellknown that the amount of smectite increases with water depth, from the shore facies to the basinal ones (Chamley, 1989). In the case under study, the significant amounts of chlorite and kaolinite, acting as indices of erosional processes is assuming a dominant detrital origin of the 
smectites. Also the lack of smectite in some samples (F106, Praid) supports this hypothesis.

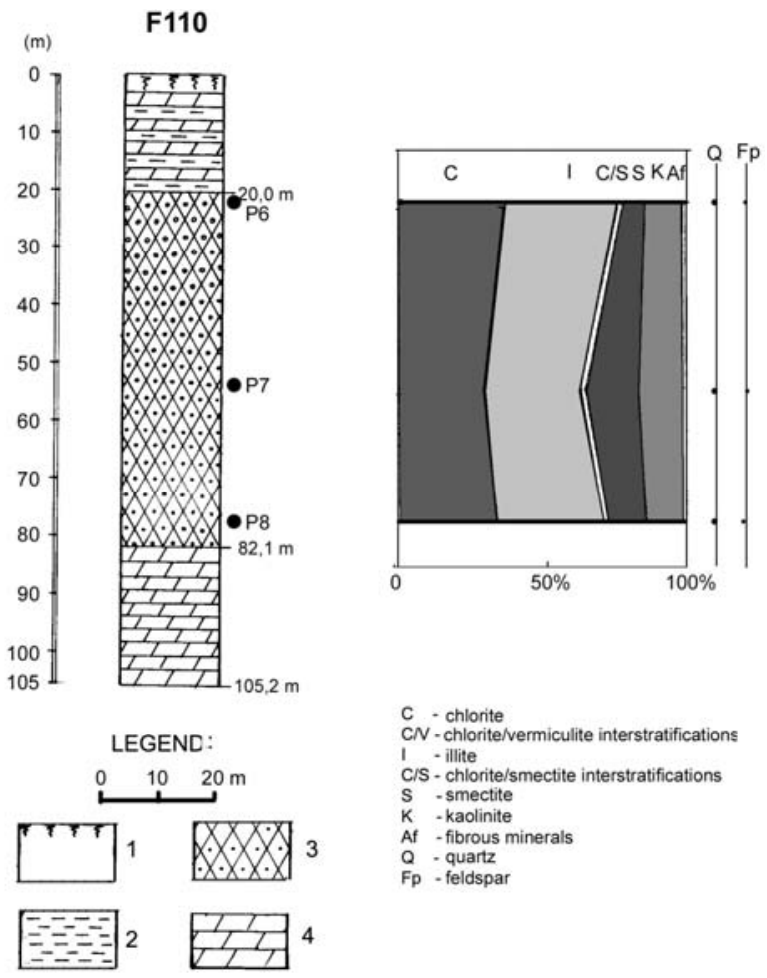

Fig. 4. Borehole F110 - Praid (same legend as for Fig. 2) P6, P7, P8 - samples submitted to XRD investigation).

However, there are three possible hypotheses for the presence of such a clay mineral association (Gibbs, 1977):

(1) Chemical (diagenetic) transformation of the clay minerals in a saline environment;
(2) Differential sedimentation processes;

(3) Physical segregation of the particles during transport and sedimentation.

Diagenesis may also lead to the transformation of vermiculite and chlorite into illite, smectite into illite and chlorite, thus to a general increase of illite content parallel to the decrease of smectite amounts. Such a diagenetic evolution may only partly explain the identified clay association. The relatively equal representation of illite and chlorite, as well as the presence of kaolinite seem to point out to another type of process.

In the same time, a rapid flocculation of kaolinite takes place under a $2 \%$ increase of salinity, leading to a fast sedimentation in slightly saline waters in the neighbourhood of the shoreline (Deconinck and Strasser, 1987). On the contrary, smectite undergoes a very slow sedimentation in waters with reduced salinity, but it flocculates fast in normal saline marine waters. As far as the Badenian saliferous basin in the Transylvanian area is concerned, the theoretical clay association calculated based on the sedimentation rates proposed by Whitehouse et al. (1960) for various salinity values would involve the following distribution: a fast sedimentation of illite and kaolinite close to the shore, and a substantial sedimentation of dominant smectite (besides minor other clay minerals) in the proximal basinal areas. Again, such a distribution is not confirmed by the investigated samples.

Even if the extrapolation of the experimental data to the more complex natural conditions (including turbulence, mineralogical mixture of the source areas etc.) renders to be difficult, the differences between the theoretical model and the analyzed case study prove that the observed mineral segregation can not be explained only by the means of flocculation mechanisms.

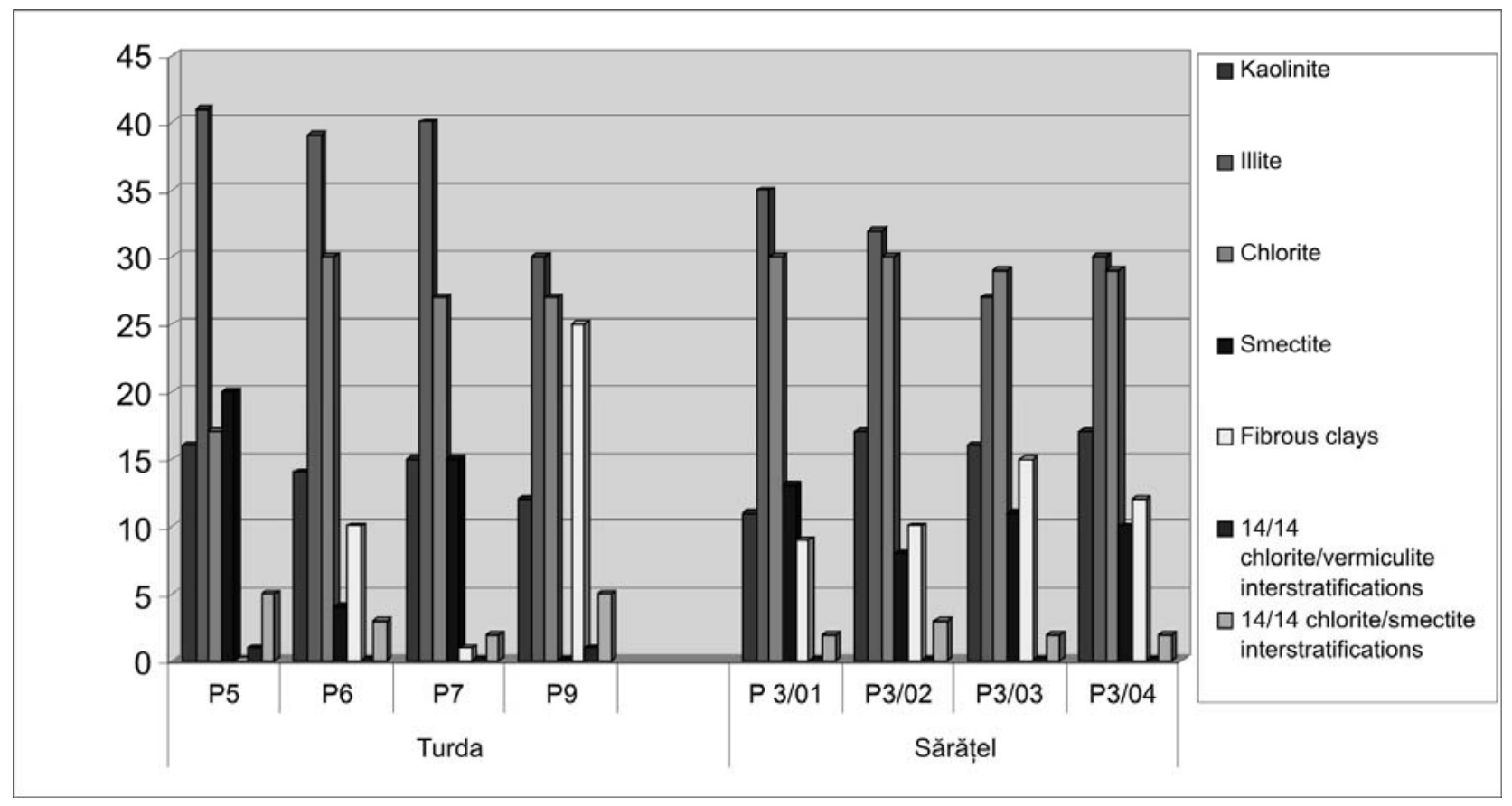

Fig. 5. Graphical representation of the quantitative (\%) distribution of the clay minerals identified in salt samples from Turda and Sărățel.

As a result, the particle size distribution may be considered as depending on the distance from the shore, being the result of gravitational segregation processes. Thus, the fine particles - the fibrous clays and the smectites $(0.1-$ 
0.9 microns) were transported towards deeper areas in the basin, as compared to the coarser particles, i.e., illite and chlorite (0.4-80 microns), and respectively kaolinite (with an average size of 1-2 microns) (Fig. 6).

In conclusion, the subordinate amounts of kaolinite and smectite as compared to chlorite and illite may be the result of differential sedimentation processes.

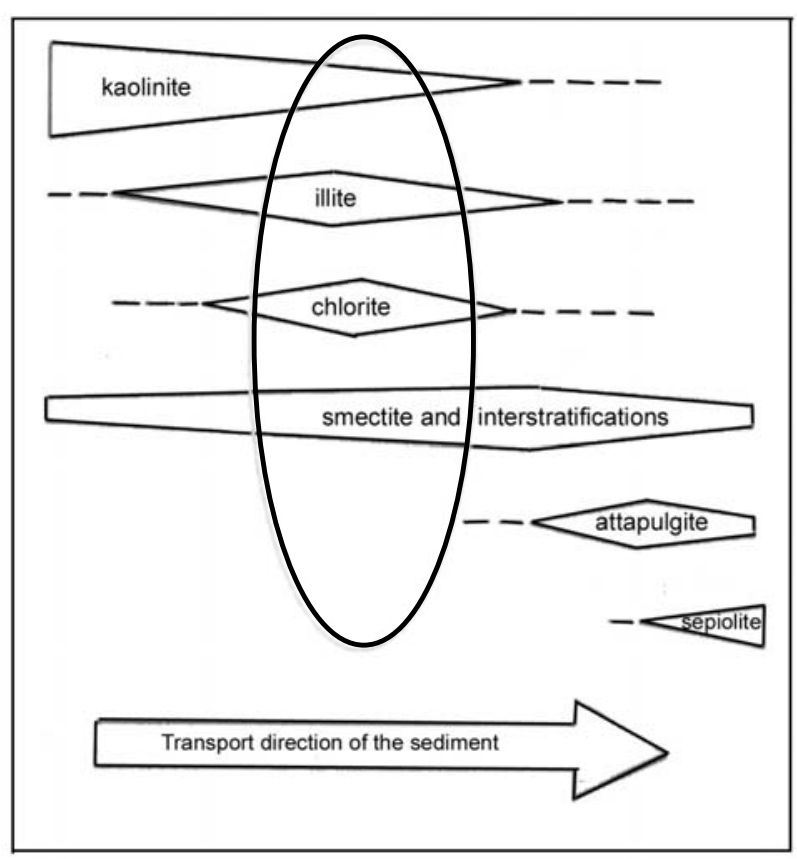

Fig. 6. Lateral variation of clay minerals distribution based on the distance of the transport (Eslinger and Peaver, 1988).

\section{b. Influence of climatic control}

Among the marine clay minerals, illite and smectite represent the most frequent phases, sometimes consisting up to $50-70 \%$ of the clay fraction in the sediment. Chlorite and kaolinite are minor components, very rarely summing up more than $50 \%$ of the clay fraction, but frequently representing less than $10 \%$.

The clay minerals distribution in the surficial sediments of the ocean basins is also related to the climate factor, as follows (Velde, 1995):

- Kaolinite is abundant in the soils from the intertropical regions, its dominance in marine sediments pleading for a major climate control. Its frequency gradually increases towards the equator in all the oceanic basins, as a result of the increased influence of hydrolysis.

- Chlorite is abundant towards higher latitudes, mainly as a result of enhanced physical erosion of magmatic and metamorphic rocks, while chemical alteration is limited. Consequently, chlorite and kaolinite distributions vary in an inverse relationship.

- The illite amounts increase towards higher latitudes, in parallel with those of chlorite. Its distribution reflects the decrease in intensity of hydrolysis, thus an enhancement of mechanical alteration.

- The distribution of the fibrous clay minerals is in many cases related to the atmospheric currents patterns, the main transport agent in the marine basins being the eolian one.

- The smectite distribution is not so straightforward, due to their double source (alteration and/or authigenesis). Under these circumstances, the climate control may become subordinate as compared to other factors, such as volcanic input.

In the case under study, the large amounts of chlorite sensitive to chemical alteration and of illite has been correlated to a reduced alteration degree of the terrigenous supply, i.e., source areas dominated by mechanical alteration and reduced intensity of hydrolysis. However, the relatively large amounts of kaolinite (occasionally reaching 34\% in F106 borehole samples from Praid) do not support this assumption.

Kaolinite results from intense hydrolysis involving, at least temporary humid stages that favored its formation and subsequent transport into the basin. The occasional high amounts of kaolinite may be correlated to local concentration due to differential sedimentation in the proximity of the continent, thus close to the shoreline.

However, the presence of smectite, that requires an alternation of humid and dry seasons for its formation, supports the same idea of a basin having a source area with a very well-defined drainage. Its presence in relatively small amounts may suggest diagenetic processes of transformation of smectite into illite (Deconinck and Strasser, 1987).

The presence of sepiolite and palygorskite (fibrous clays) in the sediments was favored by an arid climate that lead to the concentration of Mg-rich brines in the sediment, by processes of capillary evaporation as described in the Paleogene evaporitic facies of the Transylvanian Basin. Such conditions were fulfilled in the evaporitic continental environments, thus such minerals represent a suitable facies index (Hossu, 1999).

\section{CONCLUSIONS}

The clay minerals spectrum in the investigated salt samples pleads for an obvious climatic control:

$>$ Kaolinite points to altitude-controlled, well-drained source areas with intense hydrolysis under warm and humid climate;

$>$ Illite and especially chlorite suggest relatively high altitude source areas controlled by an intense mechanical alteration and a fast transport of the terrigenous supply into the sedimentation basin;

$>$ Smectite indicates the presence of littoral plains with poorly-drained vertisols formed under seasonal climatic factors;

> In parallel, evaporitic coastal environments developed, which have sustained the genesis of the Mg-rich, fibrous clay minerals.

A grain-size and mineralogical distribution pattern was noticed from the continent towards the basin. Relatively larger amounts of clay minerals were recorded in the salt residue from basinal locations, while the mineralogical composition varies as a result of differential sedimentation and diagenetic transformation. Kaolinite is dominant in marginal areas, while illite, chlorite, smectite and palygorskite become significant phases towards the basin. Such a sedimentation pattern in the marine Badenian environment was most probably the result of selective flocculation processes.

These conclusions are confirming the palynological interpretations on samples collected from the same deposits (Petrescu and Bican-Brişan, 1997; Petrescu et al., 2000; Petrescu et al., 2001; Petrescu and Bican-Brişan, 2005).

The main aspects are mentioned below (Brişan, 2004): 
The microflora points out a clear climate change during the Middle Badenian as compared to the Lower and Upper Badenian;

$>$ The high content of Pinaceae pollen and the dominance of the illite-chlorite association suggests altitude-controlled, well-drained source areas with well-defined altitudecontrolled vegetation levels developed in the proximity of the sedimentation basin;

$>$ Both the mixed composition of the spores-pollen spectrum (humid facies and xerophyte elements), and the presence of smectite and kaolinite plead for alternating humid and dry seasons;

$>$ The xerophytic microflora and the Mg-rich fibrous clay minerals (sepiolite, palygorskite) document the existence of coastal evaporitic environments.

Finally, the present study is an example of convergent results obtained by using two different methods of investigation for solving paleoenvironmental aspects of formation of the evaporitic deposits from the Transylvanian Basin.

\section{R E F E R E N C E S}

Balintoni, I., Petrescu, I. 2002, A hypothesis on the transylvanian halite genesis. Studia Universitatis BabeşBolyai, Geologia, Special issue 1: 51-61.

Brişan, N. 2004, Palinologia formațiunii cu sare din Badenianul Bazinului Transilvaniei. PhD thesis, 204 pp., Cluj-Napoca.

Chamley, H. 1989, Clay sedimentology. Springer Verlag, Berlin, 623 pp.

Deconinck, J.F., Strasser, A. 1987, Sedimentology, clay mineralogy and depositional environment of Purbeckian green marls (Swiss and Franch Jura). Eclog. Geol. Helv., 80 (3): 753-772.

Eslinger, E., Pevear, D. 1988, Clay Minerals for petroleum geologists and engineers. Society of Economic Paleontologists and Mineralogists short course, Tulsa, 22, 413 pp.
Gibbs, R.J. 1977, Clay mineral segregation in the marine environment. Journal of Sedimentary Petrology 47 (1): 237-243.

Holtzapffel, T. 1985, Les mineraux argileux. Preparation. Analyse diffractometrique et determination. S.G.N., Villeneuve D'Asq, 136 pp.

Hosu, A. 1999, Arhitectura sedimentatiei depozitelor Eocene din nord-vestul Depresiunii Transilvaniei. Ed. Presa Univ. Clujeana, Cluj-Napoca, 224 pp.

Petrescu, I., Meseşan, M. 1993, Palynological research concerning the salt-formation from Ocna Dej (Romania). Paleoclimatical approach. Contribuţii Botanice (19931994) 123-128.

Petrescu, I., Bican-Brişan, N. 1997, Contributions to the study of microflora in the salt deposits from Turda. Studia Universitatis Babeş-Bolyai, Geologia, XLII (2): 103-111

Petrescu, I., Bican-Brisan, N. \& Mera O. 2000, Paleoclimatic and environmental conditions during genesis of evaporitic formation from Turda - Cheia area (western Transylvanian Basin, Romania) based on palynological investigations. Acta Palaeontologica Romaniae, 2: 361 - 368 .

Petrescu, I., Bican-Brişan, N. \& Ciuta, C. 2001, Palynological data concerning the salt from Sărățel Bistrița. Contribuții Botanice, XXXVI: 163-171.

Petrescu, I., Stefârță, A. \& Bican-Brişan, N. 2001 a, Some remarks concerning the presence of Cedrus Link. pollen in the Badenian with salt from Romania. Contribuții Botanice, XXXVI: 173-185.

Petrescu, I., Bican-Brişan, N. 2005, First palynological data on the salt deposit from Praid (NE Transylvania), Contribuţii Botanice, XL: 301-306.

Velde, B. 1995, Composition and mineralogy of clay minerals, In Origin and mineralogy of clays (Velde, B., Ed.) Springer-Verlag, New York, 8-42.

Whitehouse, U.G., Jeffrey, L.M. \& Debbrecht, J.D. 1960, Differential settling tendencies of clay minerals in saline waters. In Clays and clay minerals. Pergamon Press, New York, 1-79. 
PLATE I
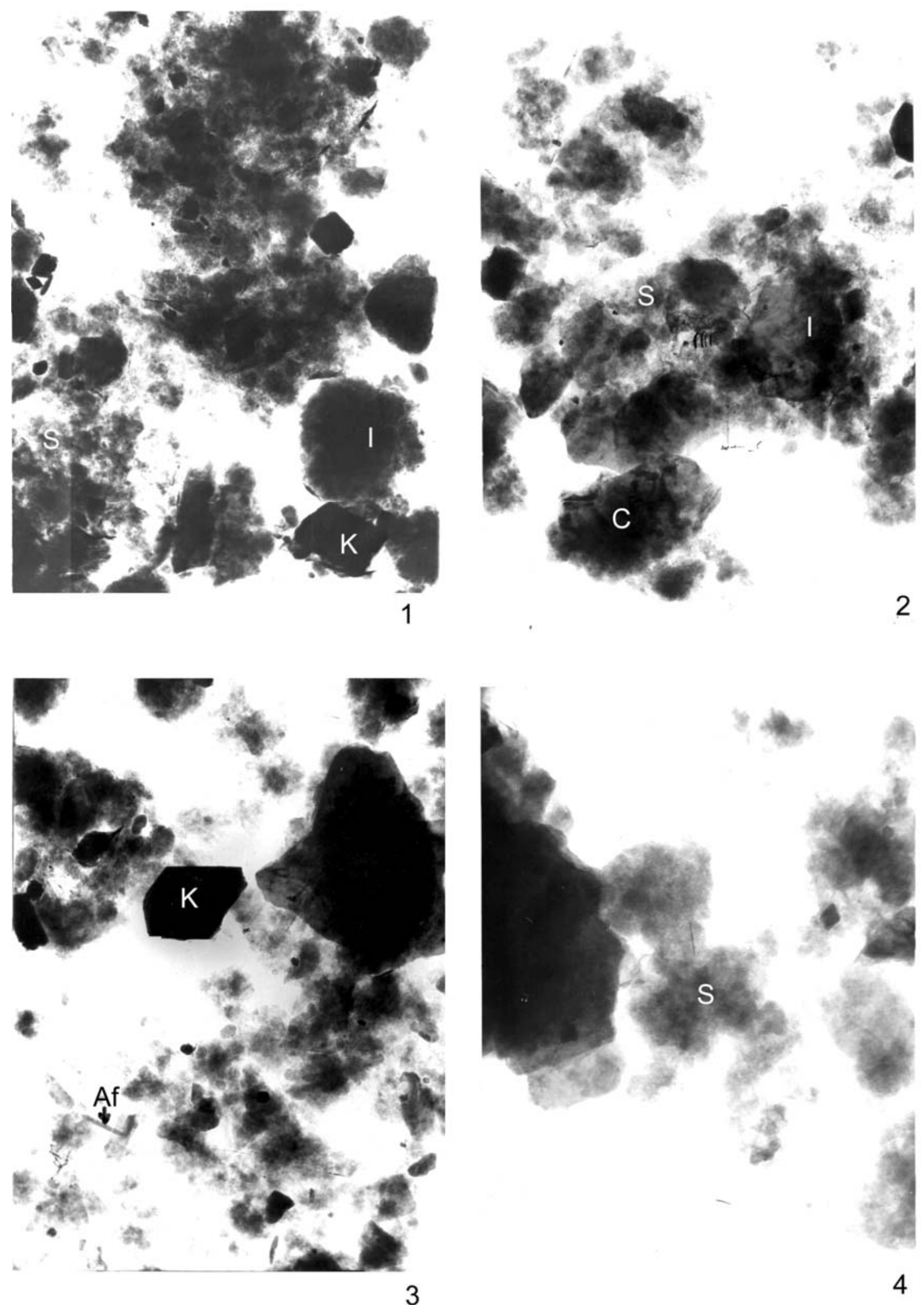

PLATE 1 Clay mineral REM images.

Fig. 1. Illite (I), Kaolinite (K), Smectite (S) - sample 5, Turda, x13200.

Fig. 2. Illite (I), Chlorite (C), Smectite (S) - sample 5, Turda, $x 22000$.

Fig. 3. Kaolinite (K), Fibrous clays (Af) - sample 6, Turda, x22000.

Fig. 4. Smectite (S) - sample 5, Turda, x70400.

Studia UBB, Geologia, 2006, 51 (1-2), 35 - 41 

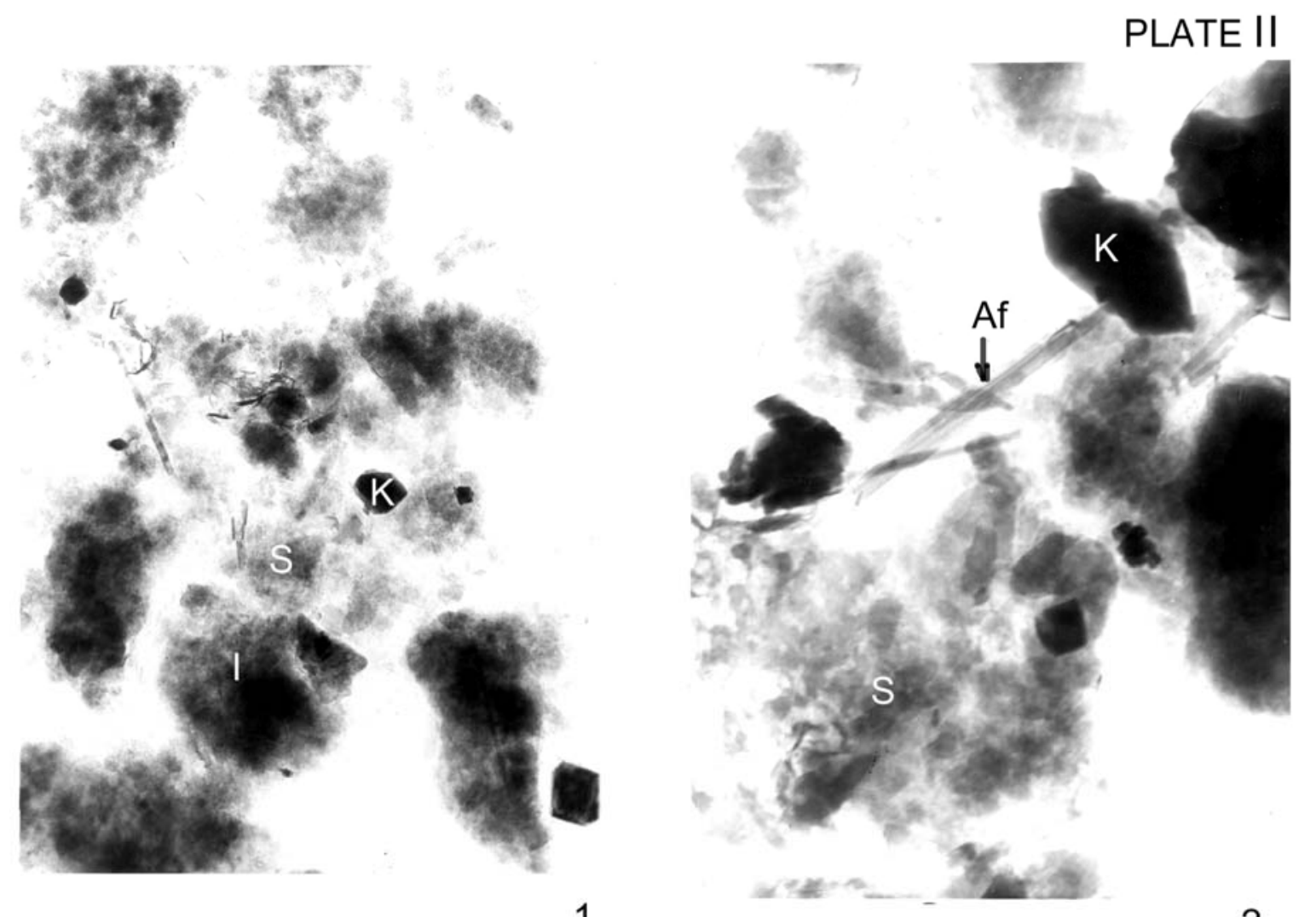

1
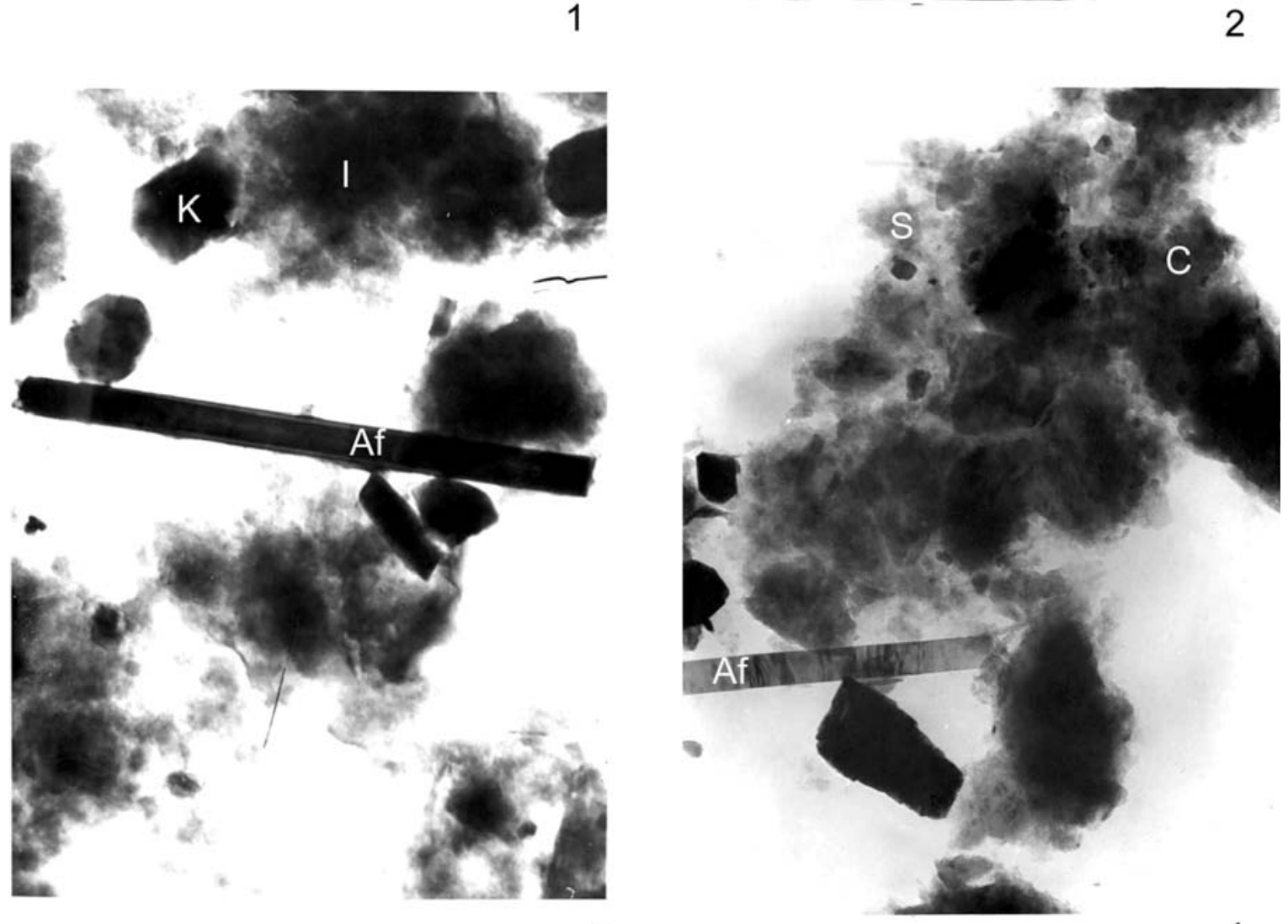

PLATE II Clay mineral REM images.

Fig. 1. Illite (I), Kaolinite (K), Smectite (S) - sample 6, Turda, x39600.

Fig. 2. Smectit (S), Kaolinite (K), Fibrous clays (Af) - sample 6, Turda, x70400.

Fig. 3. Kaolinite (K), Illite (I), Fibrous clays (Af) - sample 6, Turda, x52800

Fig. 4. Smectite (S), Chlorite (C), Fibrous clays (Af) - sample 7, Turda, x30800. 